\title{
Succession in marine benthic habitats and fauna in response to oxygen deficiency: analysed by sediment profile-imaging and by grab samples
}

\author{
Hans C. Nilsson*, Rutger Rosenberg \\ Department of Marine Ecology, Göteborg University, Kristineberg Marine Research Station, 45034 Fiskebäckskil, Sweden
}

\begin{abstract}
This study shows, for the first time, in situ images of changes in marine benthic habitats in response to oxygen deficiency. Tight coupling is demonstrated between gradual degradation of benthic habitat and faunal behaviour, species richness, abundance and biomass. The critical oxygen level that forced changes in the benthic faunal successional stages was $-10 \%$ that of air saturation $\left(\sim 0.7 \mathrm{ml} \mathrm{O}_{2}\right.$ $1^{-1}$ ). Before this critical saturation level was reached, tube-building polychaetes their tubes extended higher into the water column, the width of the sub-oxic sediment layer decreased, and vertical animal burrows (formerly oxidised and brown in colour) became sulphidic and black. Over a 10 mo hypoxic period (June 1997 to April 1998) in the Gullmarsfjord (Swedish west coast), benthic community successional stages declined from equilibrium to virtually azoic conditions. As normoxic conditions returned, pioneering stages gradually recolonised the area
\end{abstract}

KEY WORDS: REMOTS $\cdot$ SPI $\cdot$ Hypoxia $\cdot$ Anoxia $\cdot$ Melinna cristata

\section{INTRODUCTION}

Riverine inputs of nitrogen in many temperate regions have increased greatly since pre-industrial times, e.g. in the North Sea by 6 - to 20 -fold (Howarth et al 1996). In addition to this and other nutrient inputs, organic enrichment of sediments in coastal areas is increasing worldwide (Rosenberg 1985, Nixon 1995). In stratified and partly enclosed waters, areas with low oxygen concentrations critical for marine bottom-living animals are expanding, which has a negative impact on fisheries (Caddy 1993, Diaz \& Rosenberg 1995). In areas where benthic fauna has been reduced or even eliminated, sediment chemistry, including nutrient fluxes, is changing significantly, with consequences for the ecosystem (Aller 1988).

Structural changes in soft-bottom benthic communities resulting from organic enrichment have been modelled by Pearson \& Rosenberg (1978), who demonstrated how species-abundance-biomass (SAB) curves and faunal distributions in the sediment change along

•E-mail: h.nilsson@kmf.gu.se a gradient from excess organic input to 'normal' conditions (Fig. 1). This generalised successional model has also been shown to hold for physical disturbance (Rhoads \& Germano 1986) and to apply generally to disturbed sublittoral benthic communities (Heip 1995).

Since the pioneering work of Rhoads \& Cande (1971) and Rhoads \& Germano (1982), sediment-profile imaging, SPI, (Fig. 1) has proved useful in demonstrating benthic habitat changes connected with physical disturbance (Rhoads \& Germano 1986, Rumohr \& Schomann 1992), organic enrichment (O'Connor et al. 1989), low salinities (Bonsdorff et al. 1996), and low oxygen concentrations (Schaffner et al. 1992, Nilsson \& Rosenberg 1997). The effects of oxygen deficiency on the behaviour of benthic fauna at the sediment surface (Dethlefsen \& von Westernhagen 1983, Stachowitsch 1984) and the presence of sulphur bacteria (Rosenberg \& Diaz 1993, Rumohr 1993) have also been documented by in situ photography. One advantage of SPI over traditional grab sampling methods is that the organism-sediment relationship is lost in grab samples when the sediment sample is processed (Rhoads \& Germano 1982). 

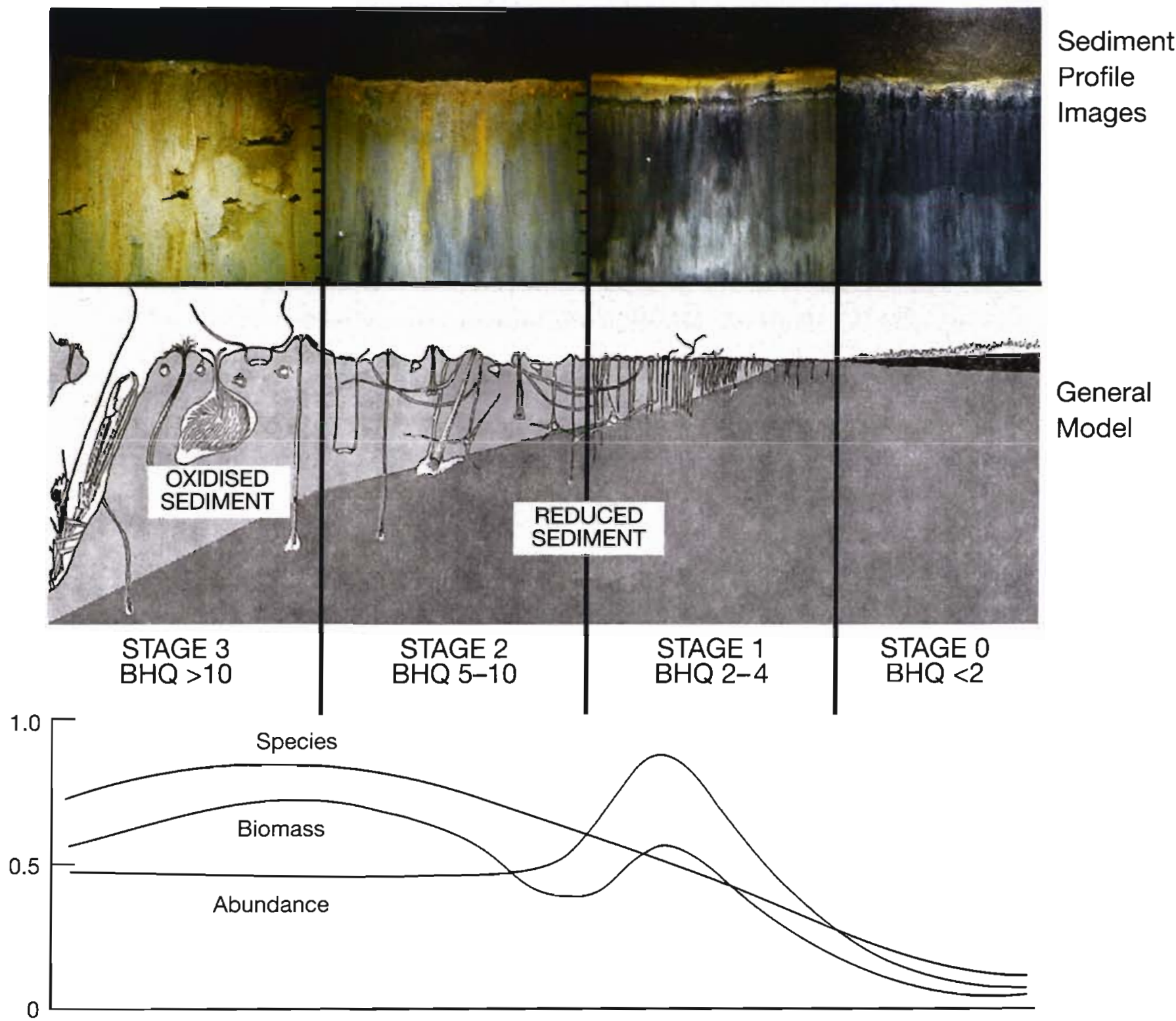

\section{Disturbance gradient}

Fig. 1. Distribution of benthic infaunal successional stages along gradient of increasing environmental disturbance (from left to right) (after Pearson \& Rosenberg 1978), and associated benthic-habitat quality (BHQ) index (Nilsson \& Rosenberg 1997). Sediment-profile images assigned to successional stage are shown above the general model (colours digitally enhanced); oxidised sediment is rust-brown, and reduced sediment grey or black. Bottom graph illustrates generalised changes in species, abundance, and biomass (after Pearson \& Rosenberg 1978)

To summarise in situ data concerning the benthic habitat, Rhoads \& Germano (1986) developed an organism-sediment index (OSI), which is calculated from the SPIs combined with measurements of dissolved oxygen over the bottom sediment. In addition to oxygen recordings, their index is based on the mean ap- parent depth of the redox potential discontinuity (RPD; Fenchel \& Riedl 1970), subjective assessment of the faunal successional stages (similar to the example in our Fig. 1), and the presence or absence of sedimentary methane. The index ranges between -10 and +11 . In a recent paper, Nilsson \& Rosenberg (1997) sug- 
gested another method for assessing successional stages of the benthic habitat, whereby surface and subsurface structures together with the mean depth of the apparent RPD are assessed and summarised as a benthic-habitat quality (BHQ) index, ranging between 0 and 15 (Table 1). The BHQ index is related to the faunal successional stages in Fig. 1, and we will demonstrate in our study that it is correlated with $\mathrm{SAB}$ curves.

This study analyses in situ SPIs of infaunal behaviour in relation to benthic-habitat responses to declining and low oxygen concentrations over a 10 mo period. These analyses are compared with changes in SAB parameters obtained from grab samples taken every second month during the same 10 mo period. The study was carried out at 6 stations (60 to $118 \mathrm{~m}$ bottom depth) in the deeper parts of the Gullmarsfjord on the Swedish west coast (Fig. 2), where salinity is $\sim 34.5 \mathrm{psu}$ and temperature 4 to $8^{\circ} \mathrm{C}$. Sediments are similar at all stations, being composed predominantly of clay with $\sim 3 \%$ organic carbon and $0.3 \%$ nitrogen. The Gullmarsfjord has a sill at $40 \mathrm{~m}$ and a maximum depth of $118 \mathrm{~m}$. The stagnant bottom water is usually renewed with cold, oxygen-rich deep water annually each spring. In 1997, however, this bottom-water exchange failed to occur, and dissolved oxygen content continued to decrease to $<10 \%$ saturation at depths $>80 \mathrm{~m}$

Table 1. Calculation of the benthic-habitat quality (BHQ) index from sediment-profile images $(B H Q=\Sigma A+\Sigma B+C$, where $A=$ surface structures, $B=$ sub-surface structures, and $C=$ mean sediment depth of apparent redox potential discontinuity, RPD. BHQ values vary between 0 and 15 , and $B H Q$ index corresponds to various successional stages in Fig. 1

\begin{tabular}{|c|c|c|c|}
\hline \multicolumn{3}{|c|}{ Faunal and sediment structures } & $\mathrm{BHQ}$ \\
\hline \multicolumn{4}{|c|}{ A: Surface structures } \\
\hline & Faecal pe & & 1 \\
\hline & Tubes & $\leq 2 \mathrm{~mm}$ diam. & 1 \\
\hline \multirow[t]{2}{*}{ or } & Tubes & $>2 \mathrm{~mm}$ diam ${ }^{\mathrm{b}}$ & 2 \\
\hline & Feeding $\mathrm{f}$ & & 2 \\
\hline \multicolumn{4}{|c|}{ B: Sub-surface structures } \\
\hline & Infauna & & 1 \\
\hline & Burrows & $\# 1-3$ & 1 \\
\hline \multirow[t]{2}{*}{ or } & Burrows & $\#>3$ & 2 \\
\hline & Oxic void & & 1 \\
\hline or & Oxic void & & 2 \\
\hline \multicolumn{4}{|c|}{ C: Mean depth of apparent RPD } \\
\hline & & $0 \mathrm{~cm}$ & 0 \\
\hline & & $0.1-1.0 \mathrm{~cm}$ & 1 \\
\hline & & $1.1-2.0 \mathrm{~cm}$ & 2 \\
\hline & & $2.1-3.5 \mathrm{~cm}$ & 3 \\
\hline & & $3.6-5.0 \mathrm{~cm}$ & 4 \\
\hline & & $5 \mathrm{~cm}$ & 5 \\
\hline \multicolumn{4}{|c|}{$\begin{array}{l}\text { "e.g. Euchone sp., Polydora sp. } \\
\text { 'e.g. Melinna sp. Terebellidae sp., Ampharetidae sp., } \\
\text { Rhodine sp. }\end{array}$} \\
\hline
\end{tabular}

(Fig. 3). It was not until January 1998 that a slight increase in oxygen saturation was recorded, followed by a major exchange of bottom water in the spring

\section{MATERIAL AND METHODS}

Beginning in June 1997, 3 replicate SPIs and 3 grab samples were collected bi-monthly from the same single stations at each of 6 depths $\{60,75,85,95,105$ and $118 \mathrm{~m}$ : Fig, 2) until April 1998. The 2 shallow stations were used as reference stations, since oxygen saturation here was comparatively high (generally $>30 \%$ : Fig. 3). These stations were compared with 4 stations between 85 and $118 \mathrm{~m}$ which had lower oxygen saturations and exhibited increasing effects on sediment and fauna with increasing depth. At the beginning of the study in June 1997, the fauna appeared to be relatively unaffected by low oxygen concentrations down to $95 \mathrm{~m}$ depth, whereas at the deeper stations, where oxygen saturation had been $<10 \%$ for several months, the fauna had been affected (see second subsection of 'Results'). In situ SPIs were taken through a prism $(30 \times 22 \mathrm{~cm}$; Rosenberg \& Diaz 1993) penetrating $\sim 12 \mathrm{~cm}$ into the sediment. The contrast of the colours was digitally enhanced in Adobe Photoshop 4.0 ; the depth of the mean apparent RPD was analysed in NIH image 1.6. From each image, a BHQ index was calculated. This index parameterises sediment structures, sub-surface structures, and the apparent depth of the RPD (Table 1), and is related to the faunal successional stages of the Pearson-Rosenberg model (Fig. 1; and Nilsson \& Rosenberg 1997). The lengths of Melinna cristata tubes above the sediment surface were digitally measured in the SPIs, a total of 119 tubes in 65 images. In images containing several visible tubes close to the prism, a maximum of 2 randomly chosen tubes were measured in each image. Macrofauna was collected with a $0.1 \mathrm{~m}^{2}$ SmithMcIntyre grab (1 $\mathrm{mm}$ sieve), and biomass is given as formalin wet weight.

Statistical analyses were made of changes in mean number of species, total abundance, total biomass, and BHQ indices before and after minimum oxygen saturation (November/December 1997) occurred. The statistical test was a nested 3-way analysis of variances (ANOVA), with 'station' and 'before/after' as fixed factors and 'time' as a nested factor in station and before/after. Multiple comparisons of means were performed using the Student-Newman-Keuls (SNK) procedure. Homogeneity of variances was examined with Cochran's C-test, and gross heterogeneity was removed by $\log (x+1)$ transformation. Numerical similarity between macrofauna samples was analysed by multi-dimensional scaling (MDS) based on the Bray- 


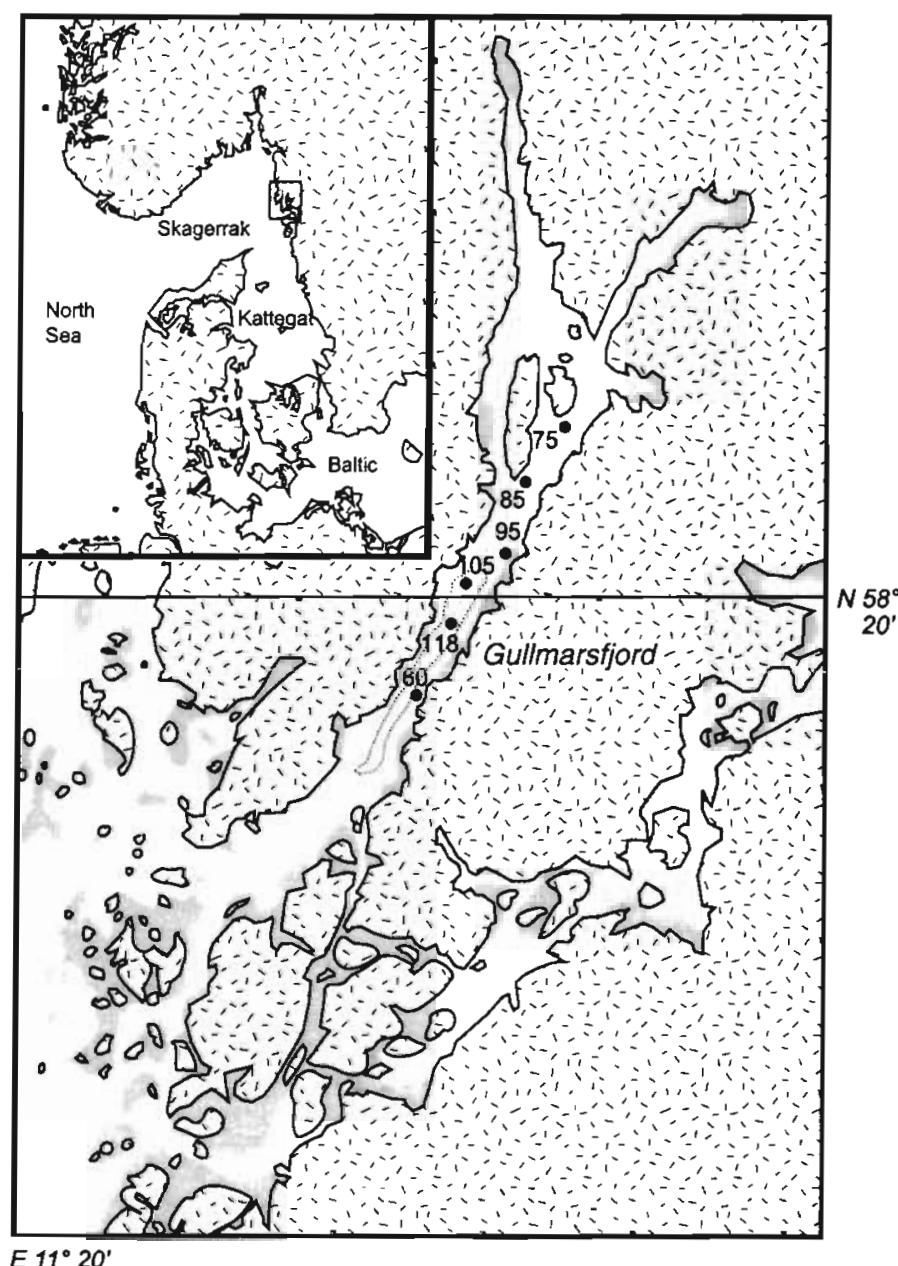

Fig. 2. Location of stations in Gullmarsfjord; numbers are depths at sampling sites period. At 85 and $95 \mathrm{~m}$, SPIs from stations in June through October 1997 were similar in appearance to that at $75 \mathrm{~m}$ as far as RPD, feeding voids and deep vertical-burrow structures. However, at 85 and $95 \mathrm{~m}$, worm tubes extended several centimetres higher into the water column. The contents of the grab samples suggest that these tubes contained Melinna cristata. This species constructs clay tubes that can extend $20 \mathrm{~cm}$ vertically into the sediment as indicated in many of the images in Fig. 4. The lengths of the tubes above the sediment in the SPIs were measured and were related to the prevailing oxygen saturations (Fig. 3). At saturations $>25 \%$ maximum tube lengths were $\leq 1.7 \mathrm{~cm}$ (Fig. 5). At saturations $\leq 15 \%$ tube lengths were variable, maximum lengths generally increasing with declining oxygen saturation. A maximum tube length of $\sim 9 \mathrm{~cm}$ was recorded at $\sim 7 \%$ oxygen saturation. At $75 \mathrm{~m}$, elongated tubes above the sediment surface were also seen in December 1997 (Fig. 4), but 2 mo later, as oxygen saturation improved, these appeared to have returned to their normal length. It appears that $M$. cristata can extend its tube higher into the water column, probably by lengthening it; it can probably also cut off the top of its tube. The SPIs from December 1997 and February 1998 at 85 and $95 \mathrm{~m}$ show M. cristata tubes bent and collapsed on the surface, and a worm that appears to be dead is visible in the $95 \mathrm{~m}$ image of December (Fig. 4). Presumably the tubes collapse after the worms die, since worm density thereafter declined in the grab samples (see below). The burrows now appeared black and re-
Curtis similarity index after $\sqrt{ } \sqrt{ }$ transformation (Clark \& Warwick 1994). Correlations between BHQ index and number of species, total abundance, and biomass were analysed by simple linear correlation $[\log (x+1)]$.

\section{RESULTS}

\section{Sediment-profile imaging}

Fig. 4 shows the sediment habitatsuccession in response to low oxygen saturations as SPIs from sites at depths of 75,85 and $95 \mathrm{~m}$ (Fig. 4). At 60 and $75 \mathrm{~m}$, the upper, rust-brown, sub-oxic layer extended deeper than $3 \mathrm{~cm}$ below the sediment surface during the entire

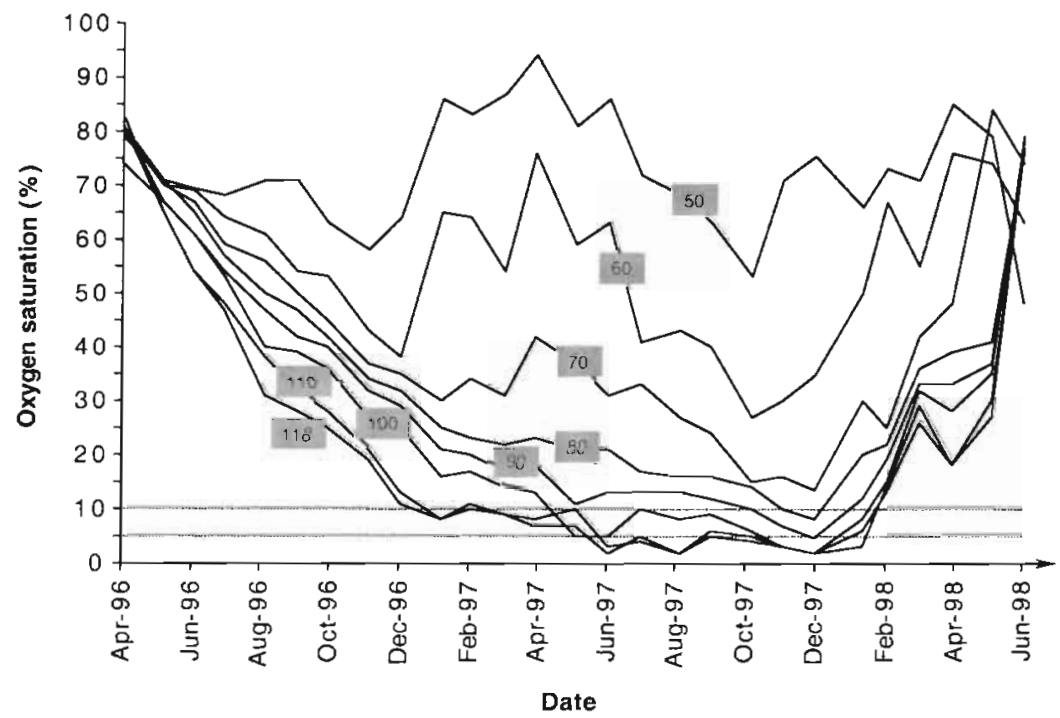

Fig. 3. Temporal changes in oxygen saturation (\%, Winkler analysis) from April 1996 to June 1998 at depths between 50 and $118 \mathrm{~m}$ (bottom) measured in water at the deepest part of Gullmarsfjord, west Sweden 

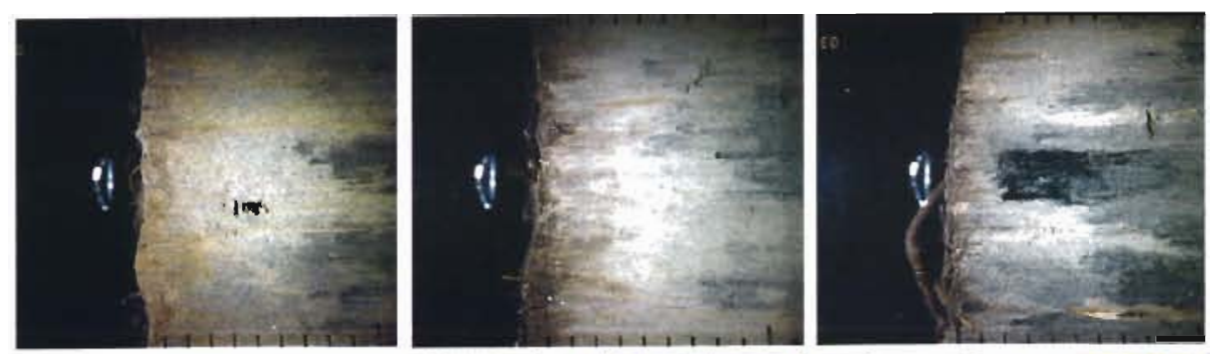

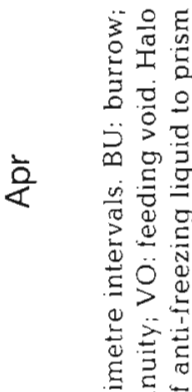
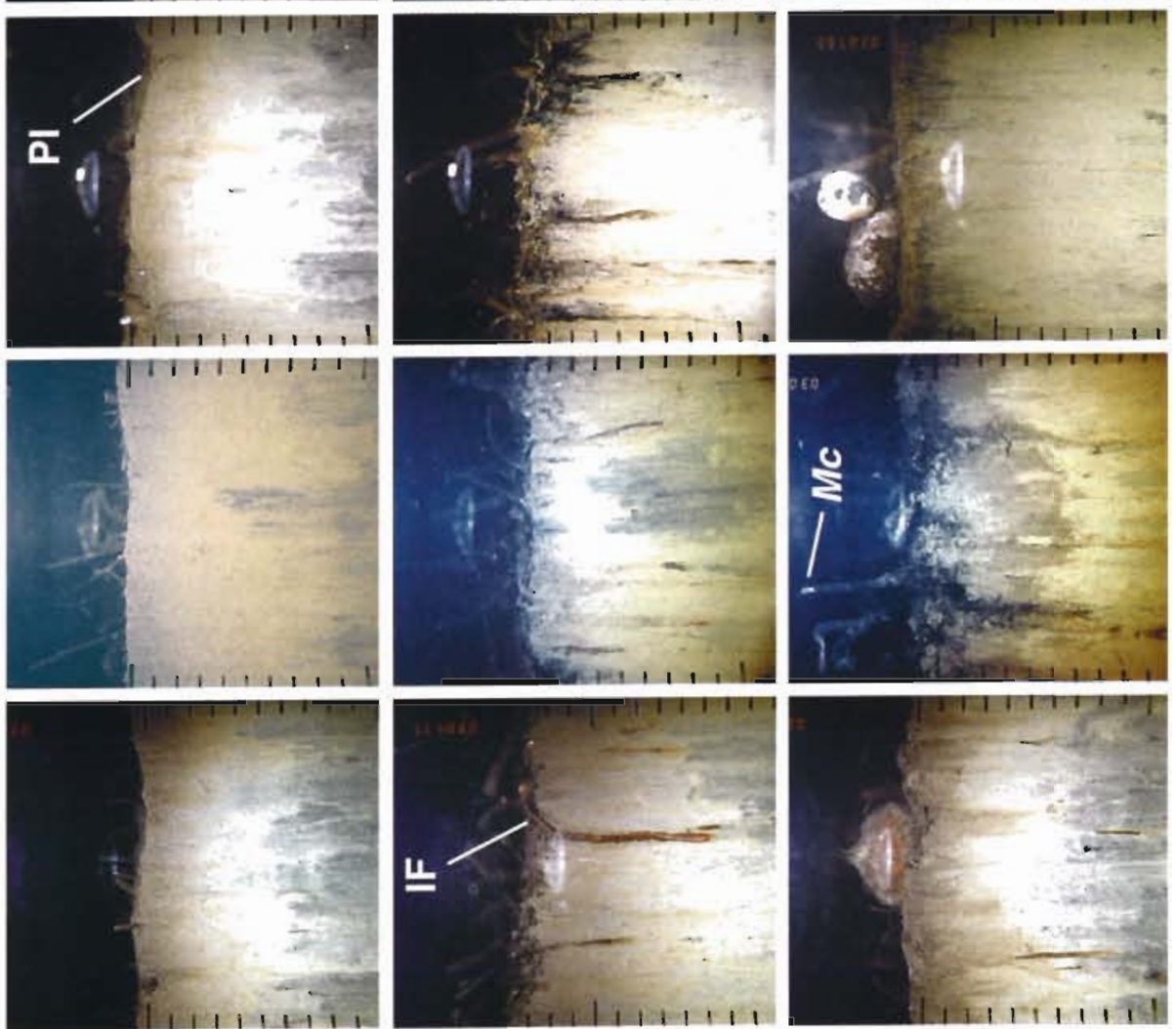

$\stackrel{g}{g}$

¿

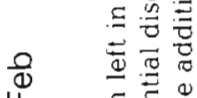

ᄂ

过 $匚$

苋

D

兽点荎

밍

导总

ญ

00

들 守

응

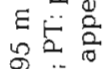

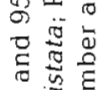

$\infty$ ¿

ए

प) $\frac{\pi}{0}$

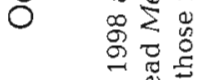

豆它远

$\frac{2}{4}$

호옹

อ

도웜

宁谷

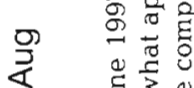

ব $\quad \stackrel{5}{3}$

토유.

존

음들

a

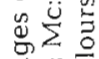

它品

ร

恶 蒠

은

它总焉

䆑志

$\stackrel{\varpi}{\pi}$

จ

过它告 


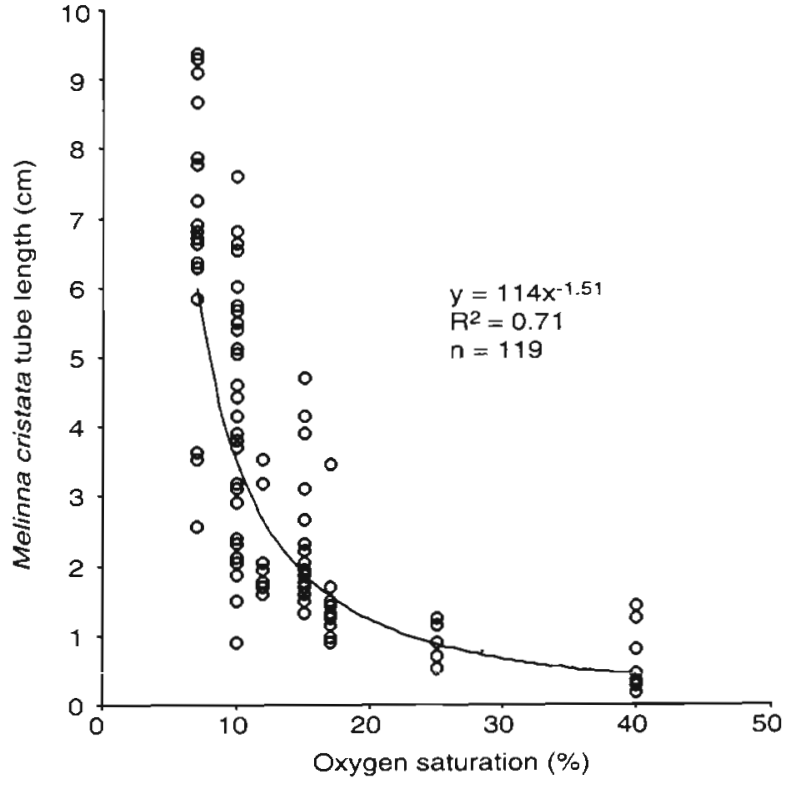

Fig. 5. Melinna cristata. Lengths of tubes above sediment surface, measured from SPIs. Lengths are presented as a function of estimated oxygen saturations in Fig. 3 at the time images were taken. Each data point represents individual measurement of 1 tube, and curve is the best-fit power function

duced, as did the sediment surface, resulting in a narrower sub-oxic zone. At $95 \mathrm{~m}$, in October 1997, a live heart sea-urchin, probably Brissopsis lyrifera, had emerged onto the sediment surface (Fig. 4). Later, in February, 2 dead sea-urchins were visible in an image from the same depth (Fig. 4). In June 1997 at $105 \mathrm{~m}$ depth, the mean apparent RPD was $\sim 3 \mathrm{~cm}$, but the sediment turned black in August 1997. No RPD was observed at $118 \mathrm{~m}$ before April 1998, when a recently sedimented, spring phytoplankton-bloom was visible in the top layer at depths $>85 \mathrm{~m}$.

\section{Species, abundance and biomass}

The 5 dominant species at all stations from the beginning and end of the survey are listed in Table 2 . Among the dominants at the 2 shallow stations were the polychaetes Heteromastus filiformis, Melinna cristata and Spiophanes kröyeri, the bivalves Abra nitida, Thyasira equalis and $T$. sarsi, and the brittle stars Amphiura chiajei and A. filiformis. M. cristata and T. equalis appeared to be among the organisms most tolerant to low oxygen concentrations: they survived at $95 \mathrm{~m}$ until April 1998 (Table 2) and occurred sparsely at $105 \mathrm{~m}$ depth even after 6 mo of exposure to oxygen saturations of $<10 \%$. The polychaete Capitella capitata was the dominant coloniser of deeper bottoms in spring 1998, while the nemertean Hubrechtella dubia colonised 85 and $95 \mathrm{~m}$ depths.

At 60 and $75 \mathrm{~m}$ depth there was comparatively little temporal change in the number of species and abundance, except for some recruitment during summer and autumn (Fig. 6). At 85 and 95 m, however, a decrease in both species richness and abundance occurred between October and December 1997. This decline coincided with a further drop in oxygen saturation to $<10 \%$. Thus, the critical oxygen saturation for survival of most benthic animals seems to be $\sim 10 \%$. At the 2 deepest stations, such critical oxygen concentrations were present before the first sampling in June 1997 (Fig. 3). Biomass largely followed patterns similar to species and abundance, but with low values being recorded at $95 \mathrm{~m}$ as early as mid-1997. No macrofauna was found at $118 \mathrm{~m}$ between August 1997 and February 1998, nor at $105 \mathrm{~m}$ in December 1997 and February 1998.

Significant interactions between station and occurrence of the oxygen minimum were observed in total

Table 2. Mean abundance (ind. $\mathrm{m}^{-2}$ ) of 5 dominant species at each station (depth) in Gullmarsfjord in June 1997 and April 1998

\begin{tabular}{|c|c|c|c|c|c|c|c|c|c|c|c|c|}
\hline \multirow{2}{*}{$\begin{array}{l}\text { Taxa } \\
\text { Abra nitida }\end{array}$} & \multicolumn{2}{|c|}{$\begin{array}{c}60 \mathrm{~m} \\
\text { Jun } 97 \text { Apr } 98\end{array}$} & \multicolumn{2}{|c|}{$\begin{array}{c}75 \mathrm{~m} \\
\text { Jun } 97 \text { Apr } 98\end{array}$} & \multicolumn{2}{|c|}{$\begin{array}{c}85 \mathrm{~m} \\
\text { Jun } 97 \text { Apr } 98\end{array}$} & \multicolumn{2}{|c|}{$\begin{array}{c}95 \mathrm{~m} \\
\text { Jun } 97 \text { Apr } 98\end{array}$} & \multicolumn{2}{|c|}{$\begin{array}{c}105 \mathrm{~m} \\
\text { Jun } 97 \text { Apr } 98\end{array}$} & \multicolumn{2}{|c|}{$\begin{array}{c}118 \mathrm{~m} \\
\text { Jun } 97 \text { Apr } 98\end{array}$} \\
\hline & 77 & 80 & 420 & 477 & 27 & & 10 & & & & & 3 \\
\hline Amphicteis gunneri & & 17 & 13 & 50 & 33 & & 103 & & & & & \\
\hline Amphiura chiaeji & 293 & 410 & 77 & 43 & & & & & & & & \\
\hline Amphiura filiformis & 323 & 367 & 97 & 107 & 7 & & & & & & & \\
\hline Capitella capitata & 10 & & & & & 43 & & 407 & & 960 & & 1300 \\
\hline Heteromastus filiformis & 600 & 450 & 470 & 790 & 187 & 13 & & 3 & 17 & 3 & 20 & \\
\hline Maldane sarsi & 3 & & 53 & 323 & & 3 & & & & & & \\
\hline Melinna cristata & 100 & 287 & 127 & 230 & 170 & 207 & 263 & 63 & 87 & & & 3 \\
\hline Hubrechtella dubia & 53 & 73 & 7 & 117 & & 180 & & 320 & & & 3 & \\
\hline Nereimyra spp. & & 3 & 27 & 53 & 93 & 233 & 80 & 10 & 13 & & & \\
\hline Nuculoma tenius & 133 & 153 & & 317 & 27 & & 113 & & 63 & & & \\
\hline Pholoe spp. & 267 & 313 & 90 & 77 & 17 & 3 & 23 & 3 & & & & \\
\hline Scalibregma inflatum & 27 & 13 & 3 & 3 & 100 & & 23 & & & & & \\
\hline Sphiophanes kröyeri & 13 & 23 & 147 & 413 & 593 & & 173 & & & & & \\
\hline Thyasira equalis $+T$. sarsi & 157 & 347 & 90 & 163 & 190 & 263 & 187 & 87 & 123 & & & 3 \\
\hline
\end{tabular}



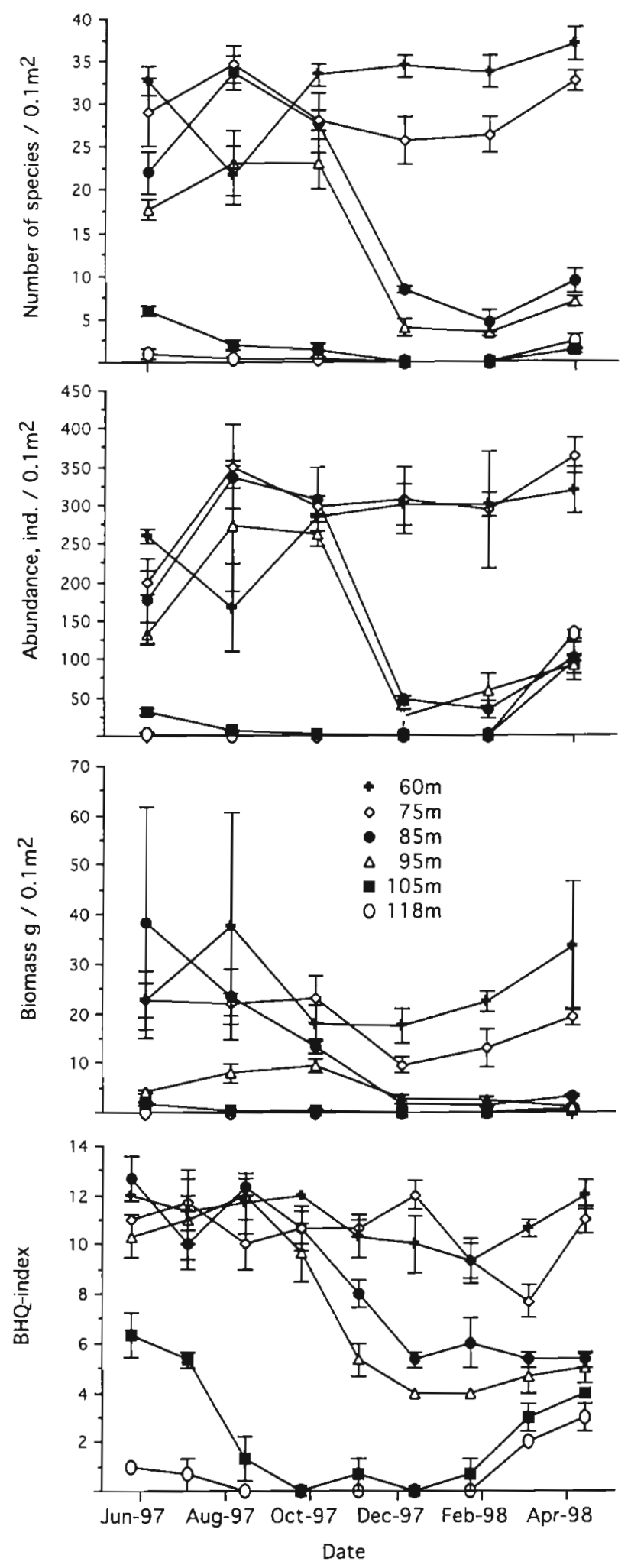

Fig. 6. Succession in number of species, abundance and biomass (means $\pm S E_{i} \mathbf{n}=3$ ) of benthic macrofauna from June 1997 through April 1998 at various depths between 60 and $118 \mathrm{~m}$. Benthic-habitat quality $\left(\mathrm{BHQ}\right.$ ) index (means $\pm \mathrm{SE}_{\text {; }}$ $\mathrm{n}=3$ ) for same period is shown in bottom graph abundance (ANOVA, $F_{524}=7.34, \mathrm{p}<0.01$ ), number of species (ANOVA, $F_{5.24}=13.65, \mathrm{p}<0.01$ ) and total biomass (ANOVA, $F_{5.24}=11.45, \mathrm{p}<0.01$ ). No significant ( $S N K, p>0.01$ ) temporal changes in mean total abundance, number of species and total biomass were observed at $118,105,75$, or $60 \mathrm{~m}$. However, at 95 and $85 \mathrm{~m}$ significantly ( $\mathrm{SNK}, \mathrm{p}<0.01$ ) lower total abundance, number of species and total biomass were recorded after the oxygen minimum level had been reached.

\section{Successional changes}

Fig. 7 presents the successional changes in the benthic communities as ordination of samples by MDS. Groups (Roman numerals) correspond to the successional stages of the Pearson-Rosenberg (1978) model (Fig. 1). The different stages are allocated according to the $\mathrm{BHQ}$ index. The MDS plot reveals similar faunal composition throughout the $10 \mathrm{mo}$ period at 60 and $75 \mathrm{~m}$ (Stage III). The 85 and $95 \mathrm{~m}$ stations were included in Stage III grouping through October 1997. but then 'moved' into Stage II with a subsequent reduction in successional stage. In June 1997, the fauna at $105 \mathrm{~m}$ also belonged to Stage II, but later moved into a separate stage (Stage 0) with further simplification of community composition. The oppor-

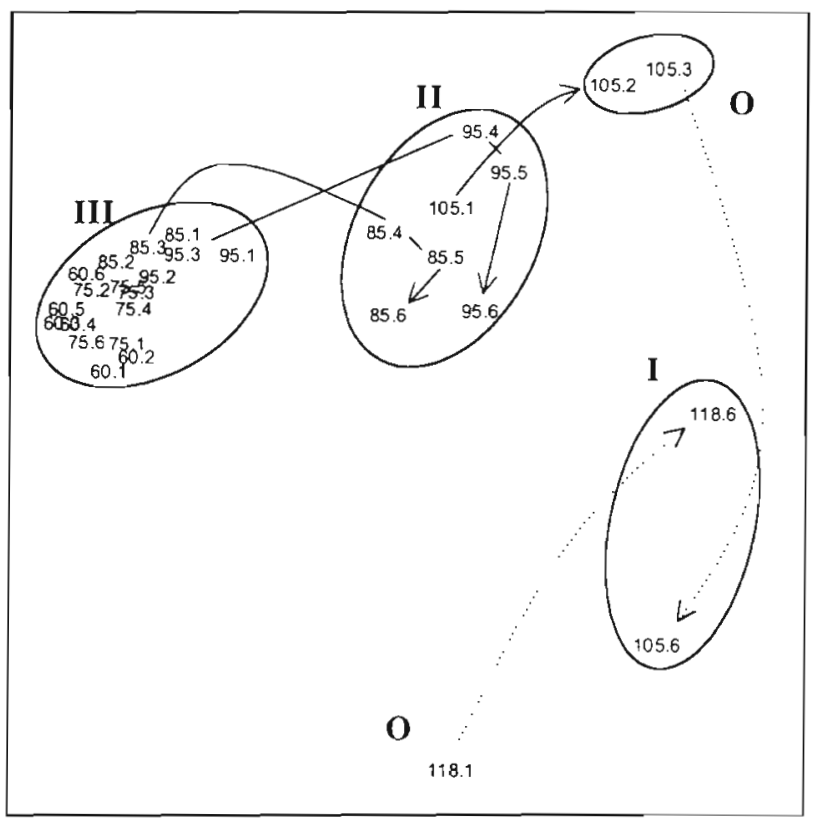

Fig. 7. Benthic faunal similarities shown as multi-dimensional scaling (MDS; stress $=0.09$ ) at different depths (first 2 digits) and sampling occasions (last digit) (e.g. $60.1=60 \mathrm{~m}$ at first sampling occasion; June 1997). 0 to III: successional stages corresponding to Pearson-Rosenberg model (see Fig. 1) 
tunistic polychaete Capitella capitata was the initial and dominant coloniser in April 1998 at the 2 deep stations when oxygen had increased to $>20 \%$ saturation (Stage I).

\section{BHQ index and correlations with number of species, abundance and biomass}

We used the SPIs to assess benthic-habitat quality with the BHQ index (which parameterises animal and sediment structures) and the depth of the mean apparent RPD observed in the images (Table 1). The mean $\mathrm{BHQ}$ index was high $(>10)$ at the 2 shallow stations, except for samples taken in March 1998 (Fig. 6). At the 2 stations at intermediate depths, similar high BHQ indices were observed until December 1997, followed by a decline. At the 2 deepest stations, significantly lower BHQ indices were observed as early as in June 1997. In March and April 1998, however, the low BHQ index at the 2 deepest stations increased in parallel to an improvement in the habitat as a response to reoxygenation of the bottom water to $>20 \%$ saturation. A significant interaction (ANOVA, $F_{5.36}=4.65, p<0.01$ ) between station and before/after the oxygen minimum was observed in the BHQ indices. No significant (SNK, p > 0.01) temporal changes in mean BHQ indices were observed at $118,105,75$, or $60 \mathrm{~m}$. However, at 95 and $85 \mathrm{~m}$ significantly (SNK, $\mathrm{p}<0.01$ ) lower $\mathrm{BHQ}$ indices were measured after the oxygen minimum level had

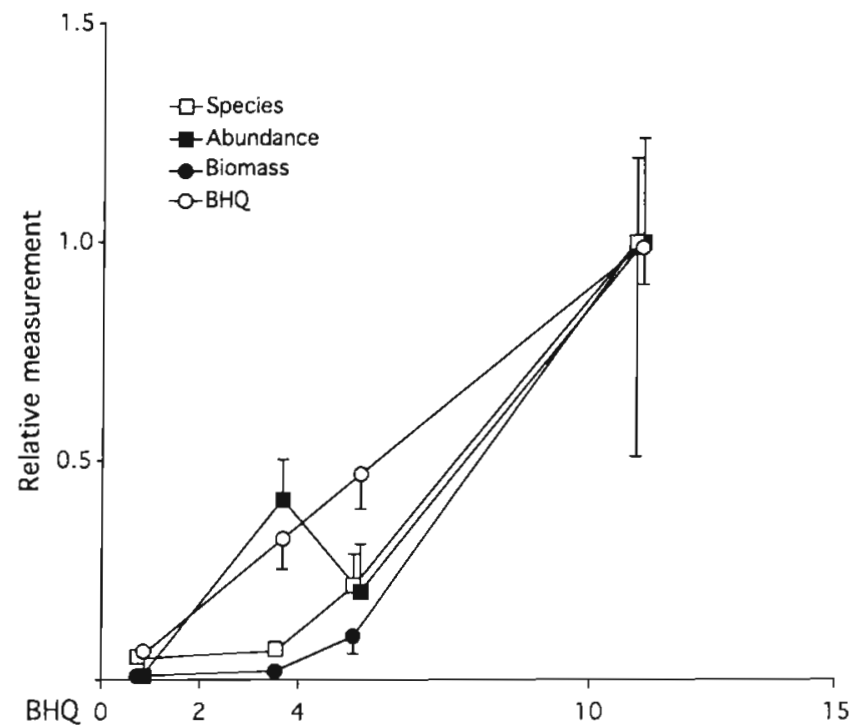

Successional stage

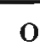

I

II

III

Fig. 8. Succession in number of species, total abundance and biomass (means \pm SD) in Gullmarsfjord between June 1977 and April 1998 based on MDS plot and BHQ index. Curves drawn to scale according to Pearson-Rosenberg model (Fig. 1) been reached. Temporal changes in the BHQ indices at the various depths in the Gullmarsfjord were correlated to those of the faunal parameters (Fig. 6). Significant relationships between the $\mathrm{BHQ}$ index and the logarithm of species richness, abundance, and biomass were observed (correlation coefficients of $\mathrm{r}=0.96$, 0.88 and 0.94 , respectively). Thus, the benthic habitat and faunal community succession were correlated, and mirrored the bioturbating activity of the fauna and its response to hypoxia. We used the successional stages in Fig. 7 to calculate mean species richness, abundance and biomass at each stage during the temporal changes in the Gullmarsfjord. Based on these means, Fig. 8 shows $\mathrm{SAB}$ curves and accompanying $\mathrm{BHQ}$ indices during the oxygen-disturbance event. The curves are drawn to scale according to the Pearson-Rosenberg model in Fig. 1. It is notable that Successional Stage II was low, indicative of a rather strong disturbance through the low oxygen concentrations in the Gullmarsfjord.

\section{DISCUSSION}

The colours in the SPIs reflect animal vertical distribution and activity (particularly irrigation effects) on biogeochemical processes and the vertical distribution of the RPD. The brown colour of the sediment surface is indicative of the presence of $\mathrm{Fe}^{+\mathrm{III}}$, and below this is the sulphidic, reduced area (Lyle 1983). Dissolved oxygen usually penetrates only a few millimetres into muddy sediment (Revsbech et al. 1980, Gundersen \& Jørgensen 1990), and in the sub-oxic zone $\mathrm{NO}^{-\mathrm{III}}$, $\mathrm{Mn}^{+\mathrm{IV}}$ and $\mathrm{Fe}^{+\mathrm{III}}$ act as oxidising agents (Aller 1988, Santschi et al. 1990). Burrowing, irrigation and feeding activity of animals oxidise a 3-dimensional matrix throughout the reduced layer. The burrow walls are important sites for nitrification-denitrification processes in the sediment, since these require a juxtaposition of oxic and anoxic micro-habitats (Jenkins \& Kemp 1984). Thus, a reduction in richness and abundance of the fauna and their associated biogenic structures will presumably increase the flux of inorganic nitrogen to the water column and enhance primary production. In the present study, the sub-oxidised layer was compressed both from below and from the surface, as can be seen in the images from December and February at 85 and $95 \mathrm{~m}$ depth (Fig. 4). Thus, irrigation of the sediment had been reduced, which affected the benthicpelagic coupling including the flux of nutrients.

We have shown for the first time how the benthic habitat and the infauna change in situ with changing oxygen concentrations. Tubes of Melinna cristata increased in height above the surface as oxygen content decreased, and then finally collapsed; except at $75 \mathrm{~m}$ 
depth, where they seemed to recover. $M$. cristata can probably lengthen and shorten its tube in response to variations in the ambient oxygen micro-climate. Long tube structures will induce turbulence in the nearbottom water layer, which may increase the oxygen supply to the viscous sublayer next to the sediment surface (Eckman \& Nowell 1984, Gundersen \& Jørgensen 1990). Other infaunal species have also demonstrated changes in positioning of tubes or burrow structures in response to critical oxygen concentrations; e.g. the polychaete Pectinaria koreni pushes its tube above the sediment surface (Nilsson \& Rosenberg 1994), and the amphipod Corophium volutator extents its burrow higher above the mud surface (Eriksson \& Weeks 1994). Similarly, under conditions of oxygen deficiency, the polychaete Malacoceros fuliginosa has been observed to stretch its body from the sediment surface high up into the overlying water (Tyson \& Pearson 1991), and the brittle stars Amphiura chiajei (Stachowitsch 1984) and Ophiura albida (Baden et al. 1990), to aggregate in elevated regions of sediment, where presumably the oxygen concentration is somewhat greater than in surrounding, flatter areas.

Elimination of macrofauna from the deepest bottoms $(118 \mathrm{~m})$ of the Gullmarsfjord as a result of low oxygen concentrations has been demonstrated on an earlier occasion: in the winter of $1979 / 1980$ by Josefson \& Widbom (1988), who recorded some of the last survivors as Heteromastus filiformis, Thyasira equalis, $T$. sarsi, and Melinna cristata, i.e. the same species that we found to be most tolerant to hypoxia in the present investigation. We suggest that the 3 last-mentioned species should be added to the list of species resistant to severe hypoxia (summarised by Diaz \& Rosenberg 1995). Infaunal dominants in the present study and in that of Josefson \& Widbom (1988) were the same and consistent over the depths investigated (Table 2). Oxygen concentrations in the deeper part of the Gullmarsfjord show a clear seasonal trend, with annually rather low $\left(<2 \mathrm{ml} \mathrm{O}_{2} \mathrm{l}^{-1}\right.$ ) concentrations (O. Lindahl pers. comm.); however such low concentrations for such a long period as in 1997/1998 have never been reported before. Our results suggest that the populations are pre-conditioned to hypoxia. As the oxygen conditions improved, the cosmopolitan opportunistic coloniser Capitella capitata was the first to appear in the deeper defaunated sediment; this was also the case in 1980 (Josefson \& Widbom 1988). The present study of longterm hypoxia indicates a critical oxygen saturation for survival of $-10 \%\left(\approx 0.7 \mathrm{ml} \mathrm{O}_{2} \mathrm{l}^{-1}\right)$, since at about this saturation great reductions in density and species richness occurred at 85 and $95 \mathrm{~m}$ depth at the end of 1997. This critical value is slightly lower than that reported for predominantly coastal areas, but higher than reported for upwelling areas (Diaz \& Rosenberg 1995) in which species have become adapted to permanently low oxygen concentrations for long periods.

The MDS (Fig. 7) shows the benthic community succession in relation to changing oxygen concentrations over time. Should oxygen saturations over the coming years remain rather high, say with minimum saturations of $>25 \%$, it is likely that the community structure at all depths would return to the original equilibrium stage as shown for Stage III in Fig. 7. This type of community was also found at $118 \mathrm{~m}$ in 1977 to 1979 by Josefson \& Widbom (1988). The recovery of benthic fauna was studied previously in an inner branch of the Gullmarsfjord. In these heavily enriched and defaunated sediments, recovery to an equilibrium stage took 5 to $8 \mathrm{yr}$ following pollution abatement (Rosenberg 1976). We suggest that the recovery is quicker in the deep part of the Gullmarsfjord because the sediment there is less organically enriched.

The changes in the benthic community showed clear similarities to the Pearson-Rosenberg model (Fig. 1), but hypoxia had a rather sudden and strong negative effect at the 2 intermediate depths in the Gullmarsfjord. As a result, the SAB curves were low in relation to the BHQ index (Fig. 8). The 'buffering capacity' of the sediment in conditions of low oxygen concentration may arise from the fact that diminishment of the RPD layer is a slow process compared to the rather abrupt effects of decreased oxygen content on fauna.

Correlations have been demonstrated between the $\mathrm{SAB}$ curves and the BHQ index; thus changes in benthic habitat quality closely parallel changes in faunal community succession. The strongest correlation was for number of species and the BHQ index. This would be expected, since the species curve increases rather smoothly from Seral Stage 0 to III (Fig. 1). In their pioneering study with SPI, Rhoads \& Germano (1982) also found that species richness generally corresponded to that inferred from in situ photos. In contrast, abundance and biomass may show peaks ('peaks of opportunists': Pearson \& Rosenberg 1978) in Seral Stage I, which would reduce the correlation. The OSI developed by Rhoads \& Germano (1986) has been used in some studies to map habitat-quality (Rhoads \& Germano 1986), to assess physical disturbances and organic enrichment (Valente et al. 1992), and to evaluate the effects of mariculture (O'Connor et al. 1989). In the 2 latter studies, low values of apparent RPD were correlated with low OSIs. Similarly, Nilsson \& Rosenberg (1997) found that the distribution of RPD corresponded well with benthic successional stages. One difference between the OSI and the BHQ index is that in the former the successional stages are determined by examining the images by eye whereas in the BHQ index, different structures in the images are scored and their summary relates to a particular seral stage (Fig. 1). 
The variables in the BHQ index seem to constitute an accurate description of a benthic habitat that reflects the successional stages of a benthic community. In this and a related study (Nilsson \& Rosenberg 1997), such correspondence has been demonstrated for coastal, oxygen-stressed areas, but the BHQ index is likely to be useful also in other areas where the PearsonRosenberg succession model is applicable. From a benthic study in New Jersey, USA, Grizzle \& Penniman (1991) concluded that SPI data are as useful as traditional data in delimiting the spatial extent of benthos effected by pollution. Thus, the BHQ index is useful as a cost-effective sediment-habitat classification and in disturbance-impact assessment.

Acknowledgements. We thank Odd Lindahl for allowing access to the oxygen recordings made within the Gullmarsfjord Control Programme, Drs Alf Josefson and Tom Pearson for comments on this manuscript, Dr Robert Diaz for discussions, and Birthe Hellman, Pia Engström and Stefan Agrenius for technical assistance. Financial support was given by the Swedish Natural Research Council and the Swedish Environmental Protection Agency.

\section{LITERATURE CITED}

Aller RC (1988) Benthic fauna and biogeochemical processes in marine sediments: the role of burrow structures. In: Blackburn $T H$, Serensen J (eds) Nitrogen cycling in coastal marine environments. John Wiley \& Sons Ltd, Chicester, p 301-338

Baden SP, Loo LO, Pihl L, Rosenberg R (1990) Effects of eutrophication on benthic communities including fishSwedish west coast. Ambio 19:113-122

Bonsdorff E, Diaz RJ, Rosenberg R, Norkko A, Cutter GRJ (1996) Characterization of soft-bottom benthic habitats of the Aland Islands, northern Baltic Sea. Mar Ecol Prog Ser 142:235-245

Caddy JF (1993) Toward a comparative evaluation of human impacts on fishery ecosystems of enclosed and semienclosed seas. Rev Fish Sci 1:57-95

Clark KR, Warwick RM (1994) Change in marine communities: an approach to statistical analysis and interpretation. National Environment Research Council, Plymouth

Dethlefsen $V$, von Westernhagen $H$ (1983) Oxygen deficiency and effects on bottom fauna in the eastern German Bight 1982. Meeresforsch Rep Mar Res 60:42-53

Diaz RJ, Rosenberg R (1995) Marine benthic hypoxia-review of ecological effects and behavioural responses of marine macrofauna. Oceanogr Mar Biol Annu Rev 33:245-303

Eckman JE, Nowell RM (1984) Boundary skin friction and sediment transport about an animal-tube mimic. Sedimentology 31:851-862

Eriksson SP, Weeks JM (1994) Effects of copper and hypoxia on two populations of the benthic amphipod Corophium volutator (Pallas). Aquat Toxic 29:73-81

Fenchel TM, Riedl RJ (1970) The sulphide system: a new biotic community underneath the oxidized layer of marine sand bottoms. Mar Biol 7:255 268

Grizzle RE, Fenniman CA (1991) Effects of organic enrichment on estuarine macrofaunal benthos: a comparison of sediment profile imaging and traditional methods. Mar Ecol Prog Ser 74:249-262

Gundersen JK, Jørgensen BB (1990) Microstructure of diffusive boundary layers and the oxygen uptake of the sea floor. Nature, Lond 345:604-607

Heip C (1995) Eutrophication and zoobenthos dynamics. Ophelia 41:113-136.

Howarth RW, Billen G, Swaney D, Townsend A, Jaworski N, Lajtha $K$, Downing JA, Elmgren $R$, Caraco $N$, Jordan $T$, Berendse F, Freney J, Kudeyarov V, Murdoch P, Zhu ZL (1996) Regional nitrogen budgets and riverine $N$ \& $P$ fluxes for the drainages to the North Atlantic Ocean: natural and human influences. Biogeochemistry 35:75-139

Jenkins MC, Kemp WM (1984) The coupling of nitrification and denitrification in two estuarine sediments. Limnol Oceanogr 29:609-619

Josefson $A B$, Widbom $B$ (1988) Differential response of benthic macrofauna and meiofauna to hypoxia in the Gullmar Fjord basin. Mar Biol 100:31-40

Lyle M (1983) The brown-green color in marine sediments: a marker of the $\mathrm{Fe}^{(\mathrm{iiii})}-\mathrm{Fe}^{(\mathrm{iij})}$ redox boundary. Limnol Oceanogr 28:1026-1033

Nilsson HC, Rosenberg R (1994) Hypoxic response of two marine benthic communities. Mar Ecol Prog Ser 115: 209-217

Nilsson HC, Rosenberg R (1997) Benthic habitat quality assessment of an oxygen stressed fjord by surface and sediment profile images. J Mar Syst 11:249-264

Nixon SW (1995) Coastal marine eutrophication: a definition, social causes, and future concerns. Ophelia 41:199-219

O'Connor BDS, Costolloe J, Keegan BF, Rhoads DC (1989) The use of REMOTS technology in monitoring coastal enrichment resulting from mariculture. Mar Pollut Bull 20: $384-390$

Pearson TH, Rosenberg $R$ (1978) Macrobenthic succession in relation to organic enrichment and pollution of the marine environment. Oceanogr Mar Biol Annu Rev 16:229-311

Revsbech NP, Sørensen J, Blackburn TH (1980) Distribution of oxygen in marine sediments measured with microelectrodes. Limnol Oceanogr 25:403-411

Rhoads DC, Cande S (1971) Sediment profile camera for in situ study of organism-sediment relations. Limnol Oceanogr 16:110-114

Rhoads DC, Germano JD (1982) Charecterization of organism-sediment relations using sediment profile imaging: an efficient method of remote ecological monitoring of the seafloor. Mar Ecol Prog Ser 8:115-128

Rhoads DC, Germano JD (1986) Interpreting long-term changes in benthic community structure: a new protocol. Hydrobiologia 142:291-308

Rosenberg R (1976) Benthic faunal dynamics during succession following pollution abatement in a Swedish estuary. Oikos 27:414-427

Rosenberg R (1985) Eutrophication-the future marine coastal nuisance? Mar Pollut Bull 16:227-231

Rosenberg R, Diaz RJ (1993) Sulfur bacteria (Beggiatoa spp.) mats indicate hypoxic conditions in the inner Stockholm Archipelago. Ambio 22:32-36

Rumohr H (1993) Erfahrungen und Ergebnisse aus 7 Jahren Benthosmonitoring in der südlichen Ostsee. In: Duinker JC (ed) Das Biologische Monitoring der Ostsee im Institut für Meereskunde Kiel 1985-1992. Inst Meereskunde Christian-Albrechts-Universität, Kiel, p 90-109

Rumohr H, Schomann H (1992) REMOTS sediment profiles around an exploratory drilling rig in the southern North Sea. Mar Ecol Prog Ser 91:303-311

Santschi P, Höhener P, Benoit G, Buchholtz-ten M (1990) 
Chemical processes at the sediment-water interface. Mar Chem 30:269-315

Schaffner LC, Jonsson P, Diaz RJ, Rosenberg R, Gapcynski P (1992) Benthic communities and bioturbation history of estuarine and coastal systems: effects of hypoxia and anoxia. In: Vollenweider $R A$, Marchetti $R$, Viviani $R$ (eds) Marine coastal eutrophication. Elsevier, Amsterdam, p 1001-1016

Stachowitsch M (1984) Mass mortality in the Gulf of Trieste:

Editorial responsibility: Otto Kinne (Editor),

Oldendorf/Luhe, Germany the cource of community destruction. Publ Stn Zool Napoli (I: Mar Ecol) 5:243-264

Tyson RV, Pearson TH (1991) Modern and ancient continental shelf anoxia: an overview. In : Tyson RV, Pearson TH (eds) Modern and ancient continental shelf. The Geological Soc, London, p 1-24

Valente RM, Rhoads DC, Germano JD (1992) Mapping of benthic enrichment patterns in Narragansett Bay, Rhode Island. Estuaries 15:1-17

Submitted: April 20, 1999; Accepted: November 22, 1999 Proofs received from author(s): April 17, 2000 